\title{
Does Customer Auditing Help Chinese Workers?
}

\author{
Guojun He* and Jeffrey M. Perloff**
}

February 2012

* University of California, Berkeley

** University of California, Berkeley and Giannini Foundation 


\section{Abstract}

Auditing by downstream firms has limited effects on Chinese firms' adherence to labor standards and other measures of blue collar workers well-being. Auditing does not affect the suppliers' blue-collar employees' wages, probability of belonging to a union, or likelihood of working overtime. However, audited firms are more likely to provide rural migrant workers pensions, business medical insurance, and unemployment insurance. 


\section{Introduction}

Does auditing by downstream firms affect how Chinese firms treat their workers? Using a large sample of firms from the National Bureau of Statistics of China's Private Sector Survey of China, we investigate the relationship between customer auditing and Chinese blue-collar workers' welfare. When we examine the relationships between auditing and welfare measures

for all employees, we find little evidence that auditing affects the firms' adherence of labor standards and raises workers' overall welfare. However, if we focus on how firms treat their most disadvantaged workers, rural migrants, we find that rural migrants in audited firms receive statistically significant higher pensions and medical and unemployment insurance.

Newspapers regularly report how Western firms, responding to public outcry in their own countries, pressure Chinese manufacturers to raise labor standard. For example, in 2012, Apple pressured Foxconn Technology Group to improve working conditions and raise pay at its Chinese factories, where it manufactures iPhones and iPads. Academics, labor activists, and non-government organizations have extensively documented labor rights violations in China over the last decade (e.g., Diamond 2003, Pringle and Frost 2003, Compa 2004, Cooke 2005). Since the late 1990s, multinational corporations have developed a variety of Corporate Codes of Conduct (CCC) as well as many auditing and monitoring mechanisms to check whether their 
suppliers, particularly in developing countries, comply with labor standards. ${ }^{1}$ Many of these groups urge companies that buy from Chinese suppliers to audit their treatment of workers.

However, few studies have investigated the impacts of customer auditing, and none as far as we know have examined the effects on Chinese firms extensively. The existing studies generally find that auditing has very limited effect on workers' welfare. For example, Locke, et al. (2007) analyzed its impacts on the improvement of working conditions using the data of Nike's suppliers in 51 countries. Their analysis suggests that Nike's efforts and investment on monitoring only produce little effects. Barrientos, et al. (2007) examined the impacts of corporate codes of labor practice on workers based on evidence from the UK Ethical Trading Initiative. They find that corporate codes may play a role in improving labor standards, but are currently doing little to challenging existing practices and social relations. Locke, et al. (2010) further compared two Mexican factories, and concluded that working conditions and labor standards are mainly the product of divergent patterns of work organization and human resource management and not of customer auditing.

We extend the existing literature by examining the effect of auditing in China, by using more extensive measures of workers' well-being, and by using more formal statistical analyses.

\footnotetext{
${ }^{1}$ For a more thorough discussion of CCC, see Jenkins (2001), Schrage (2004), and Mamic (2004).
} 
We analyze data from the China Center for Economic Research at Peking University's Private Sector Survey of China. We investigate the relationship between customer auditing and seven measures of Chinese blue-collar workers' welfare: presence of labor unions, working overtime, hourly wage, pension coverage, government-sponsored medical insurance coverage, business medical insurance coverage, and unemployment insurance coverage.

In the first section, we discuss the literature on labor conditions in China. The second section describes auditing by downstream firms. We then present our hypotheses concerning the relationship between auditing and labor welfare. The fourth section describes the survey. The following section discusses the models that we use to test the relationship between customer auditing and blue-collar workers welfare. The next section presents our empirical result. It is followed by a section on robustness checks. In the final section, we summarize the paper and draw conclusions.

\section{Literature on Working Conditions in China}

According to the literature on Chinese labor markets, many Chinese blue-collar workers are subject to labor law violations and are not treated as well as many Corporate Codes of Conduct require. Many Chinese firms ill-treat workers by paying low wages, violating their freedom of 
association, and requiring substantial overtime work without compensation Diamond 2003,

Compa 2004).

Freedom of association is an important labor standard in International Labor Organization

(ILO) Core Conventions and in various Corporate Codes of Conducts. Several studies conclude

that Chinese workers fare better if they are represented by labor unions. For example, Yao and

Zhong (2010), using the same data set that we employ, found that labor unionization is

associated with a $5.6 \%$ higher hourly wages, $1.4 \%$ fewer monthly hours of work, and a $12.3 \%$

greater pension coverage.

Chinese labor law requires that laborers work for no more than 8 hours a day and no more

than 44 hours a week on average, and that workers should be paid more if they do work longer

hours. $^{2}$ However, due to the government's limited ability or unwillingness to enforce labor

protection regulations, many firms require laborers to work extra hours for little or no extra

remuneration (Bhagwati, 1995; Baccaro, 2001; Elliot and Freeman, 2003). For example, a Hong

Kong Christian Industrial Committee's study (HKCIC, 2001) reported that 20 factories

supplying toys for well-known western brands such as Disney, Hasbro, McDonald's, and Mattel

\footnotetext{
${ }^{2}$ Overtime pays should be no less than 150 percent of the normal wages if employees are required to work overtime during regular work days; no less than 200 percent of the normal wages if the extended hours are on days of rest and no deferred rest can be taken; and no less than 300 percent of the normal wages if the extended hours are on statutory holidays.
} 
are run like "sweatshops." Workers in some of these factories were forced to work up to 16

hours a day, 6 or 7 days a week for as little as $\$ 60$ a month. The International Labor

Organization (2007) found that compensation was not paid to half of Chinese employees who

worked overtime on weekdays and one-third of those who worked overtime on holidays.

\section{Auditing by Downstream Firms}

Initially, the only auditing of Chinese firms was by their Western customers. However, more recently, some Chinese firms audit their suppliers. In our sample of Chinese industrial firms, $44 \%$ of the enterprises were reported being audited, roughly half by foreign and half by domestic customers.

Most downstream firms' auditing standards share common features such as requirements that the supplier provide the workers with a "living" wages, protect the freedom of association and right to collective bargaining, ensure employees' health and safety, provide basic social security to the employees, not discriminate, not force employees to work overtime, and not use child labor or forced labor.

The two most common means of auditing in China are third-party evaluation and direct factory evaluation. Small and middle-sized buyers typically use third-party evaluations. Before establishing a business relationship, the buyers request the suppliers obtain relevant third-party 
certificates to demonstrate their compliance with labor standards. These certificates are usually

provided by international organizations.

For example, the Social Accountability 8000 International Standard (SA8000), developed and overseen by Social Accountability International, provides guidelines for implementing or auditing labor protections in most industrial firms around the world. It sets out provisions for labor union rights, the use of child labor and forced labor, working hours, discrimination, health and safety at work, and fair pay.

To obtain SA8000 certification, a firm must be audited by a certified auditing firm or organization and pass all inspections. During an audit, a group of assessors visits the facility, inspects the firm's compliance with SA8000, checks the firm's production record, and interviews its employees about their working environment and treatment. A certified firm is audited twice a year. The SA8000 certificate expires after three years. At that point, another comprehensive evaluation must be conducted if the firm wants to maintain its certificate.

In addition to requiring SA8000 certification, downstream firms may require other thirdparty's auditing certificate, such as the Business Social Compliance Initiative (BSCI), the Ethical Trading Initiative (ETI), the Electronic Industry Code of Conduct (EICC), the International Council of Toy Industry's (ICTI) Caring, Awareness, Responsible, Ethical (CARE) Program, 
and the Worldwide Responsible Accredited Production (WRAP) program in the apparel,

footwear and sewn products industry.

Direct factory auditing is used primarily by multinational corporations, such as Best-Buy,

Disney, Macy's, Nike, Target, and Wal-Mart. These large corporations design their own auditing requirements and procedures, and use accredited assessors or their own assessors to check the factory's compliance with these standards. Such audits may be pre-announced or unannounced. During the audit, the assessors grade a facility's performance based on a comprehensive check-list, and also randomly and confidentially interview selected workers. The assessors' overall grade determines whether a firm passes the inspections or not. Typically a firm is given three chances to demonstrate that it is in compliance with local labor laws and the corporation's standards before it loses the corporation's business.

\section{Our Hypotheses}

We start by examining whether auditing is associated with an improvement in three direct measures of blue-collar workers' compensation, rights, and well-being: the workers' average wage, whether they belong to a union, and whether they are required to work overtime. We also investigate whether auditing is associated with an increase in four benefits. The survey has quantitative information on the share of workers receiving pensions, government-sponsored 
medical insurance, private medical insurance, and unemployment insurance. Some but not all Western downstream firms audit benefits. However, even if benefits are not directly audited, they are a strong signal for how workers are treated.

There is an extensive literature on U.S. efficiency wages that suggests a strong correlation between direct compensation and benefits. For example, in the relatively unregulated and lowwage U.S. agricultural labor market, a variety of studies (e.g., Hashida 1995) find that employers who provide superior benefits also tend to pay higher wages. Efficiency-wage theory explains these noncompensating wage effects in agriculture (Moretti and Perloff 2002). According to this theory, employers use deferred payments (pensions and fringes) to provide an incentive for workers to avoid being fired due to shirking, thereby allowing employers to lower their monitor expenses. Thus, we want to test whether auditing is associated with better pensions or fringe benefits for their own sake and because we believe they provide a strong indication of a better working environment.

We hypothesize that auditing is more likely to affect benefits than wages because downstream firms want to buy supplies at low cost. We expect that they prefer to enforce relatively low-cost conduct rules than those that cost more. Raising wages directly or by 
insisting that higher overtime wages be paid increases the downstream firms' costs more than insisting that insurance or other benefits be provided.

One of our main questions concerns whether auditing has a differential effect on rural, migrant workers than on urban workers. China engages in institutional discrimination against rural migrants (Knight and Song, 1999; Meng and Zhang, 2001). In accordance with China's Household Registration System, most rural workers are effectively barred from legally working in urban areas. As a result, these workers have essentially no protection from the government from ill-treatment by employers in urban areas and are typically barred from receiving government benefits. As a result, most migrant rural workers have limited access to social insurance and other benefits in urban areas and discrimination against migrant workers is common (Compa, 2004; Cooke, 2005).

Such discrimination is explained by both taste-based theories of discrimination (Becker 1957, Arrow 1973) and monopsony theories (Madden 1973). Our data set unfortunately does not distinguish between the wages paid to migrant and urban workers, but it does record the different benefits offered to these two groups of workers. As our efficiency wage argument suggests, differential benefits to rural workers may serve as a good proxy for wage differentials as well. Because eliminating discrimination against rural workers is less expensive for a downstream firm 
than raising benefits for all workers, we hypothesize that auditing may have larger effects on rural than urban workers' benefits.

Finally, we expect the effect of auditing to depend on various factors. We investigate whether auditing is more influential if the customer's market power is greater (as proxied by the relative size of the customer). We also test whether auditing by foreign customers is more effective than auditing by domestic customers, as many Western observers have claimed.

\section{Survey}

Our data set is the Private Sector Survey of China. ${ }^{3}$ The survey was designed by the China Center for Economic Research at Peking University and administered by the National Bureau of Statistics of China.

The sample covers 12 cities across China. These cities were chosen to be representative of various types of cities within China (Shen and Yao, 2009): Beijing and Chongqing are provincial-level cities; Changchun, Shijiazhuang, Xi'an are provincial capitals; Wujiang and Shunde are county-level cities; and the rest are prefectural-level cities.

Roughly 100 enterprises with annual sales income greater than 5 million yuan were randomly sampled within each city. Only firms in the "industry" category—manufacturing and

\footnotetext{
${ }^{3}$ The data and a description of the data are available at www.chinasurveycenter.org.
} 
utilities — were surveyed. This survey data set contains responses from managers from 1,267 enterprises for 2005 and accounting information for 2000-2005.

The survey was intended to measure Chinese firms' performance with respect to major social issues. The questionnaire covers nine topics: social trust, corporate social responsibility, government regulation, internal management, labor management, product-quality management, environmental protection, market environment, and financing and investments.

To conduct the survey, the research team at Peking University trained the enumerators in the Statistical Bureaus of the 12 cities. A city organizer was responsible for the overall quality of the questionnaires in his or her city. Each enumerator instructed respondents within firms as to how to interpret questions and respond appropriately. The managers in the relevant departments were asked to complete specific sections of the questionnaire. For example, the $\mathrm{CEO}$ or owner of a firm was responsible for answering the questions on the corporate social responsibility and government regulation; the human resource manager was asked to answer the internal management part and the labor protection section; the production manager responded to the product-quality management questions; and so forth.

Survey respondents were informed that the survey results would be used strictly for academic purposes and that no individual information would be released. However, it is possible 
that the firms' managers were concerned about their corporate image or legal liability and provided biased responses.

To check for such biases, we compared the firm-level survey to a supplement survey of individuals that was conducted at the same time. The survey team randomly distributed questionnaires in each city's government-sponsored employment center. The individual survey concentrated on labor issues such as labor contracts, union, working hours, social security, and safety amenities.

For working hours and union coverage, the questions on the two surveys are similar enough that we can compare response across the two surveys. Both firms and individuals were asked to report working days per week and working hours per day. In the firm survey, $51 \%$ reported that their employees worked more than the national standard 44 hours. The share in the individual survey, $48.2 \%$, was similar.

However, we found a larger discrepancy concerning labor union coverage. In the firm survey, $69 \%$ reported that the firm had a labor union. In contrast in the individual survey, only $20 \%$ of the correspondents said that there was a labor union in their enterprise, $55 \%$ of them said there was not, and the remaining $25 \%$ said they did not know. It is possible that workers are unaware of an existing union because the firm's union covers only workers in other divisions 
than those surveyed or because the union is ineffective. To address the latter issue, we use two additional measures to try to capture the labor union's power.

The firm survey asks how the firm would react to a labor dispute. Their choices were that management (1) decides; (2) negotiates with the labor union; (3) uses a local labor arbitration agency; (4) uses an other government agency; (5) goes to court; (6) others. Our "effective union" variable is one if the firm's manager reports that the firm negotiates with a labor union, and zero otherwise. Forty percent of the firms reported that they had negotiated with a labor union to deal with a labor dispute.

The firm survey also asks the manager to rank the importance of (1) the board of directors; (2) the chief executive; (3) the government; and (4) the labor union in the decision-making process as "very important," "important," or "not important." Our "important union" variable is one if the union is said to be "very important" or "important," and zero otherwise. Roughly half of the firms reported that their labor unions are important.

\section{Models Specifications}

We investigate whether auditing by downstream firms affects workers' rights and wellbeing, controlling for the type of enterprise, industry, and city. We examine the effects of auditing on seven measures of blue-collar workers' rights and well-being: (1) workers' average 
wage; and whether they (2) belong to a union, (3) work overtime, (4) receive a pension, (5) have government-sponsored medical insurance, (6) have private medical insurance, and (7) have unemployment insurance.

Our wage measure is the logarithm of the average hourly earnings, which is about 5.4 yuan $(80 \phi)$, with a standard deviation of 2.5 yuan. We estimate the wage equation using ordinary least squares (OLS).

We use three collective bargaining variables. The "union" variable is a dummy that equals one if the firm has a union ("Is there a labor union?"). In our sample, $69 \%$ of the firms have a labor union, a share that is virtually equal to the national average, $70 \%$ (NTU, 2006). We use logit to investigate the effects of auditing on whether a firm has a union, an effective union (the firm negotiates with the union to resolve labor disputes), or an important union (the union is an important decision maker within the firm).

Our overtime dummy is one if the average number of hours worked per week is greater than the legally required maximum of 44 (which is exceeded by $51 \%$ of the firms) and zero otherwise. We use logit to estimate the overtime work equation.

The survey indicates whether the various social insurance programs cover urban workers and migrant workers separately, so we can examine to what extent urban workers and migrant 
workers are affected by downstream auditing. The share of workers covered by social insurance is reported as falling in one of five quintiles: 0 to 20 percent, 20 to 40 percent, and so forth.

Because we observe shares only within ranges, we estimate these equations using a maximum-

likelihood, grouped regression technique (Stewart, 1983).

Our primary explanatory variable is whether any of the firm's customers audit its compliance with labor standards. In the survey, the firm manager was asked to fill in a table on customer auditing. The table listed how customers differ by how they are owned. The respondents needed to report if "Most of this type of customers audited the firm's compliance with labor standards," "Some of this type of customers audited the firm's compliance with labor standards," "Few of this type of customers audited the firm's compliance with labor standards," or "None of this type of customer audited." If any type of customers audited the firm's compliance with labor standards, our auditing variable is one; and zero otherwise.

We treat this variable as exogenous because we know little about the customers and have no obvious instruments. ${ }^{4}$ Thus, its coefficient should be interpreted as indicating association rather than causality.

\footnotetext{
${ }^{4}$ For example, it is possible that customers that audit "cherry pick," selecting firms that are already in compliance so they do not have to spend much effort monitoring their suppliers' behavior. However, given that many of these auditing firms are not fully in compliance with Chinese labor standards, there is little obvious support for this cherry picking hypothesis.
} 
The literature on Chinese labor markets suggests that workers' welfare may vary by firm size, type of ownership, industry, and city. We include variables to capture each of these effects.

Firm size is measured by the logarithm of average number of employees in 2005 . About $60 \%$ of the sample firms are small firms (fewer than 299 employees), $27 \%$ are medium size (300-1,999 workers), and 13\% are large firms (2,000 or more workers). Based on the literature, we expect that workers' welfare to be greater in large firms.

There are four categories of ownerships: Domestic Private Enterprises (DPEs), State Owned Enterprises (SOEs), Hongkong-Macao-Taiwan-Invested Enterprises (HMTs), and (other) Foreign-Invested Enterprises (FIEs). DPEs own nearly $70 \%$ of the firms in the sample, whereas SOEs, HMTs, and FIEs each own roughly $10 \%$ of firms. We expect SOEs and FIEs to treat workers better in general and specifically with respect to insurance benefits.

We divide the firms into eight industries according to Industrial Classification and Codes for National Economic Activities of China and International Standard Industrial Classification: mining and quarrying ( $1.1 \%$ of the sample); food products and beverages manufacturing $(9.8 \%)$; textiles, wood, leather and wearing apparel manufacturing (14.6\%); paper and paper products, office and accounting products manufacturing (4.0\%); chemicals, chemical products, rubber and plastic products manufacturing (17.6\%); metals and non-metallic mineral products 
manufacturing (15.5\%); equipment manufacturing (34.8\%); and electricity, gas and water supply

(2.6\%). City dummies are included to capture significantly economical, demographical and geographical differences among the sample cities.

\section{Results}

We start by examining the effect of auditing for all blue-collar workers on the wage, union membership, and overtime. The wage equation in Table 1 was estimated using ordinary least squares, while the three union and the overtime equations were estimated using logit. ${ }^{5}$ Customer auditing does not have a statistically significant effect (at the $5 \%$ level) on ln wage (hourly earnings), existence of a union, or overtime.

Larger firms take better care of their workers. A $1 \%$ increase in size (number of employees) is associated with a $6.5 \%$ increase in the wage. Evaluating at the mean of the other variables, a $1 \%$ increase in size is associated with about a $10 \%$ higher probability that the firm has a union, a $6 \%$ higher probability that the firm has an effective union, a $7 \%$ higher probability that the firm has an important union, and a $6 \%$ lower probability that employees work overtime.

Ownership structure also matters. Compared to the base group of private firms (DPEs), state-owned enterprises (SOEs) pay statistically significantly higher wages, are statistically

\footnotetext{
${ }^{5}$ Due to missing data, we had to drop roughly 200 observations in each regression. However, the missing observations appear to be random as they are not systematic correlated with any observed variable in the regressions or others in the data set.
} 
significantly more likely to have labor unions, and are statistically significantly less likely to require overtime, and pay higher wages; HMTs are less likely to require overtime; and FIEs pay higher wages. Many of the industry and city dummies (not reported in the table to save space) are statistically significant.

We do not have information about wages, labor union membership, or overtime by migrants and urban workers separately. However, we do have information about benefits such as pension and insurance coverage for each of these groups.

Table 2 reports the results of the grouped regressions on various benefits for migrant and urban workers separately. Customer auditing is statistically significantly associated with higher levels of social insurance coverage of migrant workers at the sample means: Pension coverage is $5.4 \%$ higher, business medical insurance coverage is $8.8 \%$ higher, and unemployment insurance coverage is $8.2 \%$ higher. Customer auditing is associated with an $8 \%$ increase in business medical insurance coverage for urban workers, but does not statistically significantly affect other benefits of urban workers.

Firm size is statistically significantly and positively associated with higher level of social insurances coverage. Blue-collar workers in big firms are treated better in all specifications. 
The estimated coefficient ranges from 0.018 to 0.056 . SOEs and FIEs are typically more willing to buy social insurances for their workers.

\section{Robustness Checks}

We conducted a variety of other experiments and robustness checks. First, if we merge the rural and urban sample and re-estimate Table 2 for all blue-collar workers, the only statistically significant effect of customer auditing is for business medical insurance: on average, blue-collar workers in audited firms are more likely to receive business medical insurance. Thus, the provision of business medical insurance is the only statistically significant effect among the seven welfare measures for blue-collar workers as a whole. ${ }^{6}$

This result may have implications for our results in Table 1, where we estimated the effect of auditing on wages, union membership, and overtime work. Because we do not have information about these measures separately for rural and urban workers, we estimated those equations for all blue-collar workers. It is possible that our finding that auditing did not statistically significantly affect wages, union members, and overtime hours may be due to aggregation of rural and urban workers.

\footnotetext{
${ }^{6}$ Of course, as we are testing multiple measures, one might appear to be statistically significant by chance. Thus, it might make more sense to use a Bonferroni adjustment in testing for significance of individual measures. If we do so, we would fail to reject the null hypothesis here.
} 
Second, we divided our auditing dummy into two separate dummies, one for auditing by foreign customers and the other for domestic auditing. If any foreign customer audits the firm's compliance with labor standards, the variable "Foreign Auditing" is set equal to one; otherwise it is zero. If any other domestic customer audits the firm's compliance with labor standards, the variable "Domestic Auditing" is set equal to one, otherwise it is zero. The regression results are presented in Table 3. In general, the foreign customer auditing coefficient is larger than the domestic auditing coefficient and its t-statistic is larger. However, we cannot reject the null hypotheses that these two coefficients are equal in each of the equation according to a likelihood ratio test of the equality of these two coefficients.

It is also possible that firms are more likely to respond to auditing by their major customers than to auditing by other customers. Thus, in Table 4, we use two auditing dummies: one for auditing by the largest customers and one for auditing by any other customers. In the insurance equations, auditing by the largest customers has a statistically significant effect, whereas auditing by other customers does not. However, again, we cannot reject the hypothesis that these two coefficients are equal in each equation.

In other experiments, we interacted the customer auditing dummy with the other right-handside variables. In no case was the coefficient on these interaction terms statistically significantly 
different than zero. That is, the effectiveness of auditing does not vary significantly by the firm's ownership category, size, or industry.

A potential problem in our analyses is that customer auditing may affect the size of firms, particularly if it increases the cost of labor. So the firm size measure may be endogenously influenced by customer auditing. We re-estimated the models in two ways. First, we dropped the firm size dummy; and second, we replaced it with the number of employees in 2000 (since $85 \%$ of the sample reported that customer auditing started after 2000). The main results with respect to customer auditing did not change in either of these experiments.

Finally, we developed and tested an "effective auditing" variable. Firms were asked to grade the effectiveness in improving the firm's standards and changing the firm's behaviors of (1) education, (2) government inspections, (3) government training and help, (4) fines and punishments, (5) quality standards, (6) pressure from competitors, (7) pressure from customers, and (8) pressure from others. The possible grades are "very effective," "fair," or "not effective." Three-quarters of the firms reported that the pressure from customers was very effective in improving the firm's standards and changing the firm's behaviors. Our "effective auditing" is one if pressure from customers is report to be very important, and zero otherwise. 
We interacted this variable with the customer auditing variable in all our regressions. In no regression was the interaction term statistically significantly different from zero.

\section{Summary and Conclusions}

Using a large survey of Chinese firms, we investigated the relationship between customer auditing on suppliers' compliance with labor standards and various measures of welfare of bluecollar workers. Our main finding is that auditing did not raise average wages of blue collar workers, make it more likely that they belonged to a union, or reduce the probability that they were forced to work overtime beyond legal limits.

We also investigated whether auditing increased the probability that workers received benefits. We distinguished between the effects of auditing on rural and urban workers because rural workers suffer from extensive legal and illegal discrimination. We hypothesized that eliminating such discrimination might be attractive because doing so would be relatively less expensive for a downstream firm than raising wages or benefits for all workers. We found that rural migrants are statistically significantly more likely to receive a pension, business medical insurance, and unemployment insurance in audited firms. (In addition, we found weak evidence that urban workers are more likely to receive business medical insurance.) 
We also tested hypotheses that auditing by certain types of firms is more effective. We found weak evidence that foreign customer auditing is more effective on benefits than domestic auditing, and that auditing by a firm's largest customer auditing is more effective than auditing by other customers.

Thus, our findings suggest that auditing has relatively little effect on Chinese workers as a whole. To the degree that auditing has any effect, it appears to be primarily on benefits and particularly those of migrant, rural workers. Given this result, it is possible that previous studies in other countries found little impact from customers auditing because they did not separately examine various subgroups of workers. 


\section{References}

Arrow, Kenneth J. 1973. The Theory of Discrimination. In Orley Ashenfelter and Albert Rees, eds. Discrimination in Labor Markets. Princeton, N.J.: Princeton University Press, pp. $3-33$.

Baccaro, Lucio. 2001. Civil society, NGOs, and decent work policies: Sorting out the issues. International Labor Organization, Geneva: ILO.

Barrientos, Stephanie, and Sally Smith. 2007. Do Workers Benefit from Ethical Trade? Assessing Codes of Labor Practice in Global Production Systems. Third World Quarterly, Vol. 28, pp. 713-729.

Becker, Gary S. 1957. The Economics of Discrimination. Chicago: University of Chicago Press.

Bhagwati, Jagdish. 1995. Trade liberalization and fair trade demands: Addressing the environmental and labour standards issues. World Economy, Vol. 18, pp. 745-759.

Chan, Anita, and Robert,J.S. Ross. 2003. Racing to the bottom: international trade without a social clause. Third World Quarterly, Vol. 24, pp. 1011-1028.

Chan, Anita. 2003. A "Race to the bottom". China Perspectives, Vol.46, pp. 41-49. 
Compa, Lance A. 2004. The struggle for worker rights in China. Justice for All. Washington DC: The Solidarity Center of AFL-CIO.

Cooke, Fang Lee. 2004. Foreign firms in China: modeling HRM in a toy manufacturing corporation. Human Resources Management Journal, Vol. 14, pp.31-54.

Diamond, Stephen F. 2003. The 'Race to the bottom' Returns: China's challenge to the international labor movement. University of California at Davis Journal of International Law \& Policy, Vol. 1039.

Elliott Kimberly Ann, and R.B. Freeman. 2003. Can labor standards improve under globalization? Washington D.C.: Institute for International Economics

Hashida, Emiko. 1995. The effects of work histories on agricultural wages. Ph.D. dissertation, University of California, Berkeley.

HKCIC. 2001. How Hasbro, McDonald's, Mattel and Disney manufacturing their toys. Hong Kong: Hong Kong Christian Industrial Committee.

International Labor Organization ILO. 2007. Average working week in China now 40 hours, but overtime is often unpaid. ILO News Beijing.

Jenkins, Rhys. 2001. Corporate Codes of Conduct: Self-Regulation in a Global Economy. United Nations Research Institute for Social Development, Geneva. 
Knight, John, and Lina Song. 1999. The rural-urban divide: Economics disparities and interactions in China. Oxford University Press, New York.

Locke, Richard M., Fei Qin, and Alberto Brause. 2007. Does monitoring improve labour standards? Lessons from Nike. Industrial and Labor Relations Review, Vol. 61, pp.3-31.

Locke, Richard M., and Monica Romis. 2010. The promise \& perils of private voluntary regulation: Labor standards and work organizations in two Mexican factories. Review of International Political Economy, Vol. 17, pp. 45-74.

Madden, Janice F. 1973. The Economics of Sex Discrimination. Lexington, MA: Heath.

Mamic, Ivanka. 2004. Implementing Codes of Conduct. Geneva: ILO.

Meng, Xin, and Junsen Zhang. 2001. The Two-Tier Labor Market in Urban China: Occupational Segregation and Wage Differentials between Urban Residents and Rural Migrants in Shanghai. Journal of Comparative Economics, Vol. 293, pp. 485-504.

Moretti, Enrico, and Jeffrey M. Perloff. 2002. Efficiency wages, deferred payments, and direct incentives in agriculture. American Journal of Agricultural Economics, vol. 84, pp. $1144-1155$

National Trade Union NTU. 2006. NTU Bluebook 2005: Promoting the Legal Rights of Employees. NTU, China. 
Pringle, Tim E., and Stephen D. Frost. 2003. The absence of rigor and the failure of implementation. International Journal of Occupational Environmental Health. Vol. 9, pp. 309-316.

Schrage, Elliot J. 2004. Promoting International Worker Rights through Private Voluntary Initiatives: Public Relations or Public Policy? University of Iowa Center for Human Rights, Iowa City.

Shen, Yan, and Yang Yao. 2009. CSR and Competitiveness: The Role of Corporate Social Responsibility in the Competitiveness and Sustainability of the Chinese Private Sector. Project Report for Sustainability of the Chinese Private Sector, Beijing: Foreign Languages Press.

Stewart, Mark B. 1983. On Least Squares Estimation when the Dependent Variable is Grouped. The Review of Economic Studies, Vol. 50, pp. 737-753.

Yao, Yang, and Ninghua Zhong. 2010. Unions Improves Chinese Workers' Welfare-Results from 1268 Firms. China Center for Economic Research Working Paper Series, 2010-04. 
Table 1

\begin{tabular}{|c|c|c|c|c|c|}
\hline & \multicolumn{4}{|c|}{ Union } & \multirow[b]{2}{*}{ Overtime } \\
\hline & ln Wage & Exists & Effective & Important & \\
\hline \multirow[t]{2}{*}{ Auditing } & -0.007 & 0.027 & 0.012 & 0.240 & 0.208 \\
\hline & $(0.022)$ & $(0.160)$ & $(0.159)$ & $(0.154)$ & $(0.147)$ \\
\hline \multirow[t]{2}{*}{ Size } & $0.063^{*}$ & $0.534 *$ & $0.239 *$ & $0.288^{*}$ & $-0.246^{*}$ \\
\hline & $(0.009)$ & $(0.077)$ & $(0.064)$ & $(0.067)$ & $(0.063)$ \\
\hline \multirow[t]{2}{*}{ SOE } & $0.184^{*}$ & $1.513^{*}$ & $0.696 *$ & $1.067^{*}$ & $-1.196^{*}$ \\
\hline & $(0.041)$ & $(0.478)$ & $(0.297)$ & $(0.341)$ & $(0.321)$ \\
\hline \multirow[t]{2}{*}{ HMT } & 0.039 & -0.273 & -0.287 & -0.507 & $-0.608 *$ \\
\hline & $(0.041)$ & $(0.277)$ & $(0.299)$ & $(0.282)$ & $(0.275)$ \\
\hline \multirow[t]{2}{*}{ FIE } & $0.072 *$ & -0.040 & -0.217 & -0.033 & -0.422 \\
\hline & $(0.034)$ & $(0.247)$ & $(0.241)$ & $(0.238)$ & $(0.231)$ \\
\hline Number of observations & 991 & 973 & 834 & 858 & 1011 \\
\hline $\operatorname{LR} \chi 2$ & & 198.4 & 116.4 & 134.1 & 230.7 \\
\hline Psuedo- $\mathrm{R}^{2}$ & & 0.164 & 0.103 & 0.113 & 0.165 \\
\hline F-statistic & 20.4 & & & & \\
\hline$\overline{\mathrm{R}}^{2}$ & 0.311 & & & & \\
\hline
\end{tabular}

Notes: Robust standard errors are shown in parentheses. All equations include industry and city dummies, which are not shown.

* We reject the null hypothesis of no effect at the $5 \%$ level. 
Table 2

\begin{tabular}{|c|c|c|c|c|c|c|c|c|}
\hline & \multicolumn{2}{|c|}{ Pension } & \multicolumn{2}{|c|}{$\begin{array}{c}\text { Government } \\
\text { Medical Insurance }\end{array}$} & \multicolumn{2}{|c|}{$\begin{array}{c}\text { Business } \\
\text { Medical Insurance }\end{array}$} & \multicolumn{2}{|c|}{$\begin{array}{c}\text { Unemployment } \\
\text { Insurance }\end{array}$} \\
\hline & Migrant & Urban & Migrant & Urban & Migrant & Urban & Migrant & Urban \\
\hline Auditing & $\begin{array}{l}0.054 * \\
(0.021)\end{array}$ & $\begin{array}{l}0.019 \\
(0.019)\end{array}$ & $\begin{array}{c}0.040 \\
(0.023)\end{array}$ & $\begin{array}{l}0.019 \\
(0.021)\end{array}$ & $\begin{array}{l}0.088 * \\
(0.022)\end{array}$ & $\begin{array}{l}0.080^{*} \\
(0.023)\end{array}$ & $\begin{array}{l}0.082 * \\
(0.023)\end{array}$ & $\begin{array}{l}-0.001 \\
(0.021)\end{array}$ \\
\hline Size & $\begin{array}{l}0.033^{*} \\
(0.009)\end{array}$ & $\begin{array}{l}0.028 * \\
(0.008)\end{array}$ & $\begin{array}{l}0.043 * \\
(0.009)\end{array}$ & $\begin{array}{l}0.029 * \\
(0.009)\end{array}$ & $\begin{array}{l}0.023 * \\
(0.009)\end{array}$ & $\begin{array}{l}0.018 * \\
(0.009)\end{array}$ & $\begin{array}{l}0.056^{*} \\
(0.009)\end{array}$ & $\begin{array}{l}0.047 * \\
(0.008)\end{array}$ \\
\hline SOE & $\begin{array}{l}0.080 \\
(0.042)\end{array}$ & $\begin{array}{l}0.141 * \\
(0.035)\end{array}$ & $\begin{array}{l}0.122^{*} \\
(0.045)\end{array}$ & $\begin{array}{l}0.191 * \\
(0.038)\end{array}$ & $\begin{array}{l}-0.023 \\
(0.045)\end{array}$ & $\begin{array}{l}0.004 \\
(0.046)\end{array}$ & $\begin{array}{l}0.126^{*} \\
(0.047)\end{array}$ & $\begin{array}{l}0.181 * \\
(0.038)\end{array}$ \\
\hline HMT & $\begin{array}{c}0.071 \\
(0.038)\end{array}$ & $\begin{array}{l}0.065 \\
(0.034)\end{array}$ & $\begin{array}{c}0.030 \\
(0.040)\end{array}$ & $\begin{array}{l}0.053 \\
(0.038)\end{array}$ & $\begin{array}{l}0.076 \\
(0.040)\end{array}$ & $\begin{array}{l}0.094 * \\
(0.042)\end{array}$ & $\begin{array}{l}0.081 * \\
(0.040)\end{array}$ & $\begin{array}{l}0.110 * \\
(0.038)\end{array}$ \\
\hline FIE & $\begin{array}{l}0.155^{*} \\
(0.033)\end{array}$ & $\begin{array}{l}0.093 * \\
(0.029)\end{array}$ & $\begin{array}{l}0.164 * \\
(0.034)\end{array}$ & $\begin{array}{l}0.122 * \\
(0.032)\end{array}$ & $\begin{array}{l}0.090 * \\
(0.033)\end{array}$ & $\begin{array}{l}0.090 * \\
(0.035)\end{array}$ & $\begin{array}{l}0.126^{*} \\
(0.034)\end{array}$ & $\begin{array}{l}0.141 * \\
(0.032)\end{array}$ \\
\hline Number of observations & 884 & 942 & 833 & 887 & 751 & 778 & 836 & 903 \\
\hline $\operatorname{LR} \chi^{2}$ & 239.64 & 245.83 & 243.3 & 267.64 & 108.22 & 93.83 & 235.02 & 345.78 \\
\hline $\begin{array}{l}\text { McKelvey-Zavoina } \\
\text { psuedo-R }{ }^{2}\end{array}$ & 0.244 & 0.238 & 0.260 & 0.268 & 0.139 & 0.117 & 0.252 & 0.327 \\
\hline
\end{tabular}

Notes: Robust standard errors are shown in parentheses. All equations include industry and city dummies, which are not shown).

* We reject the null hypothesis of no effect at the $5 \%$ level. 
Table 3

\begin{tabular}{|c|c|c|c|c|c|c|c|c|}
\hline & \multicolumn{2}{|c|}{ Pension } & \multicolumn{2}{|c|}{$\begin{array}{c}\text { Government } \\
\text { Medical Insurance }\end{array}$} & \multicolumn{2}{|c|}{$\begin{array}{c}\text { Business } \\
\text { Medical Insurance }\end{array}$} & \multicolumn{2}{|c|}{$\begin{array}{c}\text { Unemployment } \\
\text { Insurance }\end{array}$} \\
\hline & Migrant & Urban & Migrant & Urban & Migrant & Urban & Migrant & Urban \\
\hline Foreign Auditing & $\begin{array}{l}0.063 * \\
(0.027)\end{array}$ & $\begin{array}{l}0.028 \\
(0.024)\end{array}$ & $\begin{array}{l}0.037 \\
(0.028)\end{array}$ & $\begin{array}{l}0.021 \\
(0.027)\end{array}$ & $\begin{array}{l}0.096 * \\
(0.028)\end{array}$ & $\begin{array}{l}0.087^{*} \\
(0.029)\end{array}$ & $\begin{array}{l}0.095^{*} \\
(0.028)\end{array}$ & $\begin{array}{c}0.009 \\
(0.026)\end{array}$ \\
\hline Domestic Auditing & $\begin{array}{l}0.045 \\
(0.027)\end{array}$ & $\begin{array}{l}0.012 \\
(0.023)\end{array}$ & $\begin{array}{l}0.044 \\
(0.028)\end{array}$ & $\begin{array}{l}0.016 \\
(0.027)\end{array}$ & $\begin{array}{l}0.079 * \\
(0.028)\end{array}$ & $\begin{array}{l}0.074 * \\
(0.029)\end{array}$ & $\begin{array}{l}0.068 * \\
(0.028)\end{array}$ & $\begin{array}{l}-0.010 \\
(0.025)\end{array}$ \\
\hline Size & $\begin{array}{l}0.032 * \\
(0.009)\end{array}$ & $\begin{array}{l}0.027^{*} \\
(0.008)\end{array}$ & $\begin{array}{l}0.043 * \\
(0.009)\end{array}$ & $\begin{array}{l}0.029 * \\
(0.009)\end{array}$ & $\begin{array}{l}0.022 * \\
(0.009)\end{array}$ & $\begin{array}{l}0.018 * \\
(0.009)\end{array}$ & $\begin{array}{l}0.055^{*} \\
(0.009)\end{array}$ & $\begin{array}{l}0.047^{*} \\
(0.008)\end{array}$ \\
\hline SOE & $\begin{array}{l}0.080 \\
(0.042)\end{array}$ & $\begin{array}{l}0.141 * \\
(0.035)\end{array}$ & $\begin{array}{l}0.122 * \\
(0.045)\end{array}$ & $\begin{array}{l}0.191 * \\
(0.038)\end{array}$ & $\begin{array}{l}-0.023 \\
(0.045)\end{array}$ & $\begin{array}{l}0.004 \\
(0.046)\end{array}$ & $\begin{array}{l}0.126^{*} \\
(0.047)\end{array}$ & $\begin{array}{c}0.182 \\
(0.038)\end{array}$ \\
\hline HMT & $\begin{array}{l}0.069 \\
(0.039)\end{array}$ & $\begin{array}{l}0.064 \\
(0.035)\end{array}$ & $\begin{array}{l}0.031 \\
(0.040)\end{array}$ & $\begin{array}{l}0.053 \\
(0.038)\end{array}$ & $\begin{array}{l}0.074 \\
(0.040)\end{array}$ & $\begin{array}{l}0.092 * \\
(0.042)\end{array}$ & $\begin{array}{c}0.079 \\
(0.040)\end{array}$ & $\begin{array}{l}0.108 * \\
(0.038)\end{array}$ \\
\hline FIE & $\begin{array}{l}0.153 * \\
(0.033)\end{array}$ & $\begin{array}{l}0.091 * \\
(0.029)\end{array}$ & $\begin{array}{l}0.165^{*} \\
(0.034)\end{array}$ & $\begin{array}{l}0.121 * \\
(0.032)\end{array}$ & $\begin{array}{l}0.088 * \\
(0.034)\end{array}$ & $\begin{array}{l}0.089 * \\
(0.036)\end{array}$ & $\begin{array}{l}0.124 * \\
(0.034)\end{array}$ & $\begin{array}{l}0.139 * \\
(0.032)\end{array}$ \\
\hline Number of observations & 884 & 942 & 833 & 887 & 751 & 778 & 836 & 903 \\
\hline $\operatorname{LR} \chi^{2}$ & 239.96 & 246.15 & 243.35 & 267.66 & 108.48 & 93.99 & 235.64 & 346.17 \\
\hline McKelvey-Zavoina psuedo- $\mathrm{R}^{2}$ & 0.244 & 0.238 & 0.26 & 0.268 & 0.139 & 0.118 & 0.252 & 0.327 \\
\hline
\end{tabular}

Notes: Robust standard errors are shown in parentheses. All equations include industry and city dummies, which are not shown.

* We reject the null hypothesis of no effect at the $5 \%$ level. 
Table 4

\begin{tabular}{|c|c|c|c|c|c|c|c|c|}
\hline & \multicolumn{2}{|c|}{ Pension } & \multicolumn{2}{|c|}{$\begin{array}{c}\text { Government } \\
\text { Medical Insurance }\end{array}$} & \multicolumn{2}{|c|}{$\begin{array}{c}\text { Business } \\
\text { Medical Insurance }\end{array}$} & \multicolumn{2}{|c|}{$\begin{array}{c}\text { Unemployment } \\
\text { Insurance }\end{array}$} \\
\hline & Migrant & Urban & Migrant & Urban & Migrant & Urban & Migrant & Urban \\
\hline Biggest Customer Auditing. & $\begin{array}{l}0.023 \\
(0.030)\end{array}$ & $\begin{array}{l}0.000 \\
(0.027)\end{array}$ & $\begin{array}{l}0.064 * \\
(0.031)\end{array}$ & $\begin{array}{l}0.055 \\
(0.030)\end{array}$ & $\begin{array}{l}0.109 * \\
(0.031)\end{array}$ & $\begin{array}{l}0.116^{*} \\
(0.032)\end{array}$ & $\begin{array}{l}0.069 * \\
(0.031)\end{array}$ & $\begin{array}{c}0.021 \\
(0.029)\end{array}$ \\
\hline Rest Customers Auditing & $\begin{array}{l}0.047 \\
(0.028)\end{array}$ & $\begin{array}{l}0.024 \\
(0.026)\end{array}$ & $\begin{array}{l}0.041 \\
(0.030)\end{array}$ & $\begin{array}{l}-0.006 \\
(0.029)\end{array}$ & $\begin{array}{l}0.063 * \\
(0.029)\end{array}$ & $\begin{array}{l}0.055 \\
(0.031)\end{array}$ & $\begin{array}{l}0.054 \\
(0.030)\end{array}$ & $\begin{array}{l}-0.029 \\
(0.028)\end{array}$ \\
\hline Size & $\begin{array}{l}0.037 * \\
(0.010)\end{array}$ & $\begin{array}{l}0.033 * \\
(0.009)\end{array}$ & $\begin{array}{l}0.049 * \\
(0.010)\end{array}$ & $\begin{array}{l}0.040 * \\
(0.010)\end{array}$ & $\begin{array}{l}0.026^{*} \\
(0.010)\end{array}$ & $\begin{array}{l}0.018 \\
(0.011)\end{array}$ & $\begin{array}{l}0.063 * \\
(0.010)\end{array}$ & $\begin{array}{l}0.062 * \\
(0.010)\end{array}$ \\
\hline SOE & $\begin{array}{c}0.074 \\
(0.047)\end{array}$ & $\begin{array}{l}0.095 * \\
(0.041)\end{array}$ & $\begin{array}{c}0.087 \\
(0.050)\end{array}$ & $\begin{array}{l}0.162 * \\
(0.044)\end{array}$ & $\begin{array}{l}-0.033 \\
(0.049)\end{array}$ & $\begin{array}{l}-0.024 \\
(0.050)\end{array}$ & $\begin{array}{c}0.088 \\
(0.050)\end{array}$ & $\begin{array}{c}0.146 \\
(0.044)\end{array}$ \\
\hline HMT & $\begin{array}{c}0.043 \\
(0.045)\end{array}$ & $\begin{array}{c}0.033 \\
(0.042)\end{array}$ & $\begin{array}{c}0.017 \\
(0.047)\end{array}$ & $\begin{array}{c}0.024 \\
(0.046)\end{array}$ & $\begin{array}{c}0.047 \\
(0.048)\end{array}$ & $\begin{array}{c}0.020 \\
(0.050)\end{array}$ & $\begin{array}{c}0.067 \\
(0.047)\end{array}$ & $\begin{array}{l}0.089 * \\
(0.045)\end{array}$ \\
\hline FIE & $\begin{array}{l}0.161 * \\
(0.038)\end{array}$ & $\begin{array}{l}0.090 * \\
(0.035)\end{array}$ & $\begin{array}{l}0.145^{*} \\
(0.039)\end{array}$ & $\begin{array}{l}0.089 * \\
(0.038)\end{array}$ & $\begin{array}{l}0.102 * \\
(0.039)\end{array}$ & $\begin{array}{l}0.103 * \\
(0.041)\end{array}$ & $\begin{array}{l}0.158 * \\
(0.039)\end{array}$ & $\begin{array}{l}0.128 * \\
(0.037)\end{array}$ \\
\hline Number of observations & 685 & 723 & 647 & 684 & 596 & 616 & 650 & 700 \\
\hline $\operatorname{LR} \chi^{2}$ & 209.16 & 178.01 & 205 & 210.02 & 97.77 & 78.7 & 217.41 & 284.66 \\
\hline McKelvey-Zavoina psuedo- $\mathrm{R}^{2}$ & 0.271 & 0.226 & 0.279 & 0.272 & 0.157 & 0.124 & 0.292 & 0.343 \\
\hline
\end{tabular}

Notes: Robust standard errors are shown in parentheses. All equations include industry and city dummies, which are not shown.

* We reject the null hypothesis of no effect at the $5 \%$ level. 